\title{
Correction to: Paenibacillus sp. A59 GH10 and GH11 Extracellular Endoxylanases: Application in Biomass Bioconversion
}

\author{
Silvina Ghio ${ }^{1}$ - Ornella Ontañon ${ }^{2,3} \cdot$ Florencia E. Piccinni ${ }^{2,3} \cdot$ Rubén Marrero Díaz de Villegas $^{2} \cdot$ Paola Talia $^{2,3}$. \\ Daniel H. Grasso ${ }^{1,4}$. Eleonora Campos ${ }^{2,3}$ (D)
}

Published online: 8 May 2019

(C) The Author(s) 2019

\section{Correction to: BioEnergy Research (2018) 11:174-190 https://doi.org/10.1007/s12155-017-9887-7}

The article Paenibacillus sp. A59 GH10 and GH11 Extracellular Endoxylanases: Application in Biomass Bioconversion, written by Silvina Ghio, Ornella Ontañon, Florencia E. Piccinni, Rubén Marrero Díaz de Villegas, Paola Talia, Daniel H. Grasso and Eleonora Campos, was originally published electronically on the publisher's internet portal (currently SpringerLink) on 6 December 2017 without open access.

With the author(s)' decision to opt for Open Choice the copyright of the article changed on May 2019 (c) The Author(s) 2019 and the article is forthwith distributed under the terms of the Creative Commons Attribution 4.0
International License (http://creativecommons.org/licenses/ by/4.0/), which permits use, duplication, adaptation, distribution and reproduction in any medium or format, as long as you give appropriate credit to the original author(s) and the source, provide a link to the Creative Commons license and indicate if changes were made.

The original article has been corrected.

Open Access This article is distributed under the terms of the Creative Commons Attribution 4.0 International License (http:// creativecommons.org/licenses/by/4.0/), which permits unrestricted use, distribution, and reproduction in any medium, provided you give appropriate credit to the original author(s) and the source, provide a link to the Creative Commons license, and indicate if changes were made.

Publisher's Note Springer Nature remains neutral with regard to jurisdictional claims in published maps and institutional affiliations.

The online version of the original article can be found at https://oi.org/ $10.1007 / \mathrm{s} 12155-017-9887-7$

Eleonora Campos

campos.eleonora@inta.gob.ar; eleonoracampos@yahoo.com

1 Instituto de Suelos, CIRN, Instituto Nacional de Tecnología Agropecuaria (INTA), Hurlingham, Buenos Aires, Argentina

2 Instituto de Biotecnología, CICVyA, Instituto Nacional de Tecnología Agropecuaria (INTA), Los Reseros y N. Repetto, Hurlingham B1686, Buenos Aires, Argentina

3 Consejo Nacional de Investigaciones Científicas y Técnicas (CONICET), Ciudad Autónoma de Buenos Aires, Argentina

4 Departamento de Ciencia y Tecnología, Universidad Nacional de Quilmes, Bernal, Buenos Aires, Argentina 